\title{
Postcolonialism and the Soviet Union. Epp Annus, Soviet Postcolonial Studies: A View from the Western Borderlands (London and New York: Routledge, 2018)
}

Kaarel Piirimäe

\author{
DOI: 10.7592/methis.v17i21/22.14594
}

Keywords: postcolonialism; Soviet Union; Baltic States

I have been asked to comment, as a sort of "ordinary historian", upon the research of Epp Annus, which has recently been published in her monograph Soviet Postcolonial Studies: A view from the Western Borderlands (Annus 2018a). In actual fact her research has spanned the last couple of decades, of which the aforementioned book is an admirable culmination, a summation (see a selection of Annus' earlier works at the end of the article). Annus won recognition for her postcolonial perspective on Baltic history in 2016, when the special issue with the Journal of Baltic Studies she edited (Annus 2016) won the annual Vilis Vītols Prize. Recognizing the importance of that issue as a theoretically rich collection of articles exploring all three Baltic countries, it has now been published by Routledge as a book (Annus 2018b).

The reasons for asking an historian such as myself to write on Annus' research pursuits are probably disclosed, indirectly, by a few remarks by Annus herself about the reluctance of Estonian historians, sociologists and ethnologists to engage seriously with postcolonial critical theory, while scholars in literary analysis, visual arts, film and dance studies have readily acknowledged the usefulness of such perspectives (Annus 2018a, 64).

At this point I gladly take the liberty to describe my own scholarly background, an approach nowadays favoured in some research fields over pretences of strict objectivity. My more or less serious engagements with "Soviet studies" began as far back as in the late 1990s and the early 2000s. As far as I remember, and checking notes from those times, in those days, scholars still debated about the utility of the model of Totalitarianism, as the focus of research had been shifting from the ostensibly all-permeable state terror toward the everyday life of Soviet citizens-the approach suggested by the so-called revisionist school. Instead of the notions of control, brainwashing, and atomization of society (Arendt 1951), historians approached Soviet society not as a mass of people passively reacting to government pressure, but as a society that had retained some complexity, reconstituted social hierarchies, even undergone an "embourgeoisement" (Fitzpatrick 1999) under the Stalinist regime. 
There was interest in social mobility and the uprootedness of Stalinist society, which some argued caused control problems for the state and brought with it coercion, labour discipline, passport laws and terror (Getty 1985). Magnetic Mountain by Stephen Kotkin was published in 1995, and its importance was great for its depiction of ordinary people not as passive captives of a counterrevolutionary and criminal Stalinist bureaucracy, but flesh-and-blood people who sensed that they were engaged in a great civilizational project. After this, I must admit, I have viewed the development of Soviet studies only from the margins, as my own interest shifted to international history, even though there was a short period when I did some research on Soviet foreign propaganda, and even more recently I have become interested in the "new political thinking" in the Gorbachev era. However, this is political and international, not social history.

As to postcolonial theory, I have approached this superficially from the point of view of a lecturer who has tried to introduce young students to the latest developments in the discipline of history. Like Terry Eagleton, who has complained about not having received a copy of the secret "samizdat handbook" of postcolonialism (Eagleton 1999), I have found the theories a little inaccessible or even obscure for someone who has not been part of the sect from the earliest days. Indeed, the style of many postcolonial thinkers (Gayatri Spivak, Homi Bhabha, but not Edward Said) seems to follow the rule: "Be as obscurantist as you can decently get away with" (Eagleton 1999), which is really surprising, considering the postcolonialists' ethos of speaking for the interests and feelings of the postcolonial world, which in their view is pretty much the entire planet.

My perplexity has not been much alleviated by reading about postcolonialism from secondary sources. For example, the mostly quite comprehensible chapter by Rochona Majumdar in the recent companion edited by Marek Tamm and Peter Burke, Debating New Approaches to History (Majumdar 2018), suffers from the mistake that seems to be chronic for postcolonialism - the overambition to explain virtually anything. For example, there is the idea that postcolonialism is about the criticism of the nation state on a global scale. Therefore, Majumdar places mass protests of the 1960s in South Africa, Palestine, India, Pakistan, Vietnam, Hungary, and Poland in the same category of the "disappointment of many colonized peoples at the failure of their respective nation states to deliver on the promises of modernization, alleviation of poverty, forms of inequality, and varieties of prejudice" (49). I very much doubt that protests in Poland and the 1956 uprising in Hungary expressed criticism of the nation state la similar awkward reference to "several eastern European states" is on page 60). 
Placing widely different phenomena in the same category is a mistake that children learn to avoid in kindergarten school, where they are asked to cross out objects that do not match with others (sorry for this analogy, I have a child of this age). I do not want to infer that this is a common problem in the work of Epp Annus, but it does raise eyebrows if the "construction of nations, railroads, factories" is mentioned in the same sentence (Annus 2018a, 112). But because this rests on the constructivist ontological premise that "reality is shaped into existence by ways of legitimizing certain modes of talking about it" (33), the thought that factories are built and nations formed in an essentially same way, namely by way of talking, should not surprise us.

I have found the constructivist analyses of Western orientalist thought and discursive practices by Edward Said, or Larry Wolff, highly valuable and though provoking, but I am not equally impressed by postcolonial "theories". I agree with Prasenjit Duara that postcolonialism is not a theory, which presupposes axioms of secular rationality, but a "perspective pointing to another cosmology" (Duara 2018, 65), which apparently has an anti- or post-Enlightenment ethos (or perhaps a claim to "emotional truth", see Annus 2018a, 125). It is a position of critique toward Western-centred modernity, but Duara is correct to point out that "critique is only a critique". It is not scholarship but an effort, a successful one, to bring the anti-colonial struggle into the heart of the former metropolises, and therefore primarily a political, not a scholarly, endeavour.

Having said this about postcolonialism, I must return to Soviet studies. Reading Epp Annus' book on Soviet colonialism in the Baltic states, I am impressed by the high level of research that has been conducted in this field over the recent years, upon which Annus can build her own original analysis and conceptualisations. Most of this research (on the Soviet period in Baltic history) has been conducted in social and cultural history, and literary studies, with studies on Baltic song festivals, folk dance, post-war gossip, architecture and design, postcolonialism in "Soviet travelogues" and the like standing out as particularly interesting and innovative research pursuits.

In contrast, research on political history seems to be lagging in terms of new conceptual horizons, which might explain some lapses in the otherwise admirable "philosophical rigour" of Annus' book. How else should one explain the emphasis on the "manufacturing of consent" by the regime on the one hand (Annus 2018a, 36) and the reference to "totalitarian control" (101) on the other. I had hoped that, as a result of new social history of the USSR, we were past the paradigm of Totalitarianism, but apparently not quite, and it still begs the question, how can one reconcile the two approaches, one speaking against the view that the Soviet Union 
exerted nonconsensual control and the other arguing just the opposite? Perhaps this is just an author's oversight and not an inconsistency characterizing postcolonial perspectives.

Yet, let us pause for a moment on the idea of "manufacturing consent". For me, this seems one of the Foucauldian notions with a claim to universality, which is thought provoking and interesting, but somewhat out of place if applied to some real historical cases. Take for example the Soviet deportations in the Baltic states in 1949, which broke the resistance of the peasantry to collectivization. According to my own family's story, after the deportations, from which my grandparents were for unknown but certainly random reasons excluded, my grandfather along with other farmowners was summoned and told that there were two ways, one to Siberia and the other to Communism. There was no one who chose Siberia and so the kolkhoz was formed. Now, was this non-consensual control or manufacturing consent? Did my grandfather consent to rendering his property, his life's work, and his time to the kolkhoz, or did he do it because he essentially had no other option if he wanted his family to survive? In these perhaps extreme but still very real cases, poststructuralist theorizing and fancy language do not appear to bring a new epistemic quality.

In many other, or rather in most cases the postcolonial approach introduced by Annus produces excellent results, perhaps most convincingly in her discussion of whether the Soviet Union in general and Soviet occupation of the Baltic states in particular were exercises in colonialism. Many scholars have been reluctant to regard the Soviet Union as a colonial power, because in contrast to the European empires it had no overseas colonies, but was controlling a contiguous land mass; it was to some extent engaged in "nation-building"; and the Russians represented a majority, but Russian nationalism was not encouraged and even suppressed (Hosking 2001). I think Annus (2018a, 70) shows brilliantly that despite the rhetoric of national self-determination and the equality of all ethnic groups, Russians were always considered the big brother and, in actual fact, to cite George Grabowicz, "a Russian labourer could feel superior to a Ukrainian intellectual" for the Russian culture was deemed to be greater than all other cultures.

Besides, nation building has always been part of colonial practice, as the assumption that other ethnies need enlightenment and guidance towards Modernity is a typical colonial discourse placing people subjected to the nation-building effort in a position of dependency. Moreover, it did not follow from the teleological model of Modernization that the nations that could successfully progress on the ladder of civilization could become equal to the great Russian nation and perhaps acquire a more independent role, because, as Annus wittily puts it, "the Soviet family romance did not include space for adult peers, not even in imagined future" (117). 
Annus is also brilliant in showing how in Russian colonialism feelings of superiority toward subject nations mixed with the sense of inferiority and subaltern impulses toward the West. The situation was particularly complex in the Baltic states, which as the Russians acknowledged was more Western than the rest of the USSR, but the dilemma could still be overcome by references to the supposedly far superior Russian culture la common assumption among the Russian minorities in the Baltic countries even todayl. I agree that the idea of catching up with and surpassing the capitalist West was one of the goals of the Soviet Union throughout its history, but I am not sure whether feelings of inferiority manifested in all periods in the same degree. Stalin, for example, was not much guided by those inferiority complexes, especially when the defeat of Nazi Germany had plainly vindicated his industrialisation drive. Besides, in contrast to most other Bolsheviks he had little knowledge of the Capitalist world, having been abroad only once-in Vienna before the First World War (where he wrote his most important treatise on Marxism and the National Question) and that experience had not impressed him much (Montefiore 2008, 261-264). Feelings of inferiority would be much more important for later Soviet leaders (Khrushchev's tour of the United States in 1959 being an interesting, amusing and contradictory case).

Another interesting aspect that Annus points out is the mutually constitutive nature of the colonizer-colonized relationship, which she illustrates well with an example drawn from the memoirs of Andrei Hvostov: when a Russian immigrantstudent asks her co-student to teach her the Estonian language, the latter refuses, thus knowingly or unknowingly contributing to the persistence of the cultural barrier supporting the colonizer-colonized divide (Annus 2018a, 186).

This is in many respects an admirable book and will be required reading for anyone interested in the Soviet legacy in the Baltic countries. It suffers only from the ambition of postcolonialism to offer a kind of total interpretive paradigm and the author's wish to engage with that cosmology at all costs, thus sometimes leading to sweeping generalisations, such as "To establish a colonial-type political, economic, and cultural order in a developed modern nation-state requires deportations and executions on a massive scale...", which ignores contemporary cases such as the US 2003 invasion of Iraq, or that massive resettlement operations need an "advanced phase of modernization", which disregards premodern examples of mass resettlements common already in the earliest polities in ancient Mesopotamia (101). There is also an awkward attempt to explain the famine of the 1930s, including the holodomor, by referring to an imbalance between ideas and material possibilities (111), whatever that means; examples of over-interpretation include the claim that upon becoming pioneers "girls and boys cease to exist" (124); also there are questionable 
assertions like "cultural abundance was available only for manual workers" (121) or that the Soviet project entailed an "equal treatment of men and women" (112; it can be argued that women were not liberated from home but had a double burden of keeping a job and running an household). When Annus writes of the different "sensorium of the summer home" as a factor bringing down the Soviet Union (239), it seems that she speaks form her own experience and from the perspective of a Soviet intellectual, whereas it could be pointed out that a large part of the population lived in pre-war and pre-Soviet housing and thus in another "sensorium" anyway, and that tilling a garden had never been prohibited by the regime, not even under Stalin. One could also think of certain sports, which were either encouraged by the regime, accepted reluctantly or which were forced underground, such as mountaineering, orienteering or bodybuilding, as spaces of escape from the Soviet routine. Anyway, this is an interesting idea, which deserves a more thorough research.

To end with a personal note, it seems that I share with Annus quite a similar experience of the Soviet Union. Quite subjectively, for me it has not been a question that the Soviet Union was a colonial power, but I also understand the passion with which Annus explains this to foreign audiences, for whom the association of Colonialism and Communism has been difficult to fathom and cope with lwith the Soviet Union and the Communist movement seemingly in the forefront of the anticolonial struggle during the Cold War). However, I think this can be done without taking over all of the questionable "cosmology of Postcolonialism".

\section{Ref e r e n c e s}

Annus, Epp. 2007. “Postkolonialismist sotskolonialismini.” Vikerkaar 22 (3): 64-76.

Annus, Epp. 2011. “Postkolonialismi pealetung post-sovetoloogias: kas paradigmamuutuse künnisel? The Rise of Post-Colonialism in Post-Soviet Studies: Witnessing the Paradigm Change." Methis. Studia humaniora Estonica, no. 7: Nõukogude aja erinumber, edited by Sirje Olesk and Tiina Saluvere, 10-25. https://doi.org/10.7592/methis.v5i7

Annus, Epp. 2011. "The Conditions of Soviet Colonialism." Interlitteraria 16 (2): 441-450.

Annus, Epp. 2012. “The Problem of Soviet Colonialism in the Baltics." Journal of Baltic Studies 43 (1): 21-45. https://doi.org/10.1080/01629778.2011.628551.

Annus, Epp. 2014. "Layers of Colonial Rule in the Baltics: Nation-building, the Soviet rule and the affectivity of a nation." In (Post-)Colonialism Across Europe: Transcultural History and National Memory, edited by Dirk Göttsche and Axel Dunker, 359-384. Bielefeld: Aisthesis.

Annus, Epp. 2015. "The Ghost of Essentialism and the Trap of Binarism: Six theses on the Soviet empire." Nationalities Papers 43 (4): 595-614. https://doi.org/10.1080/00905992.2014.999314.

Annus, Epp. 2018a. Soviet Postcolonial Studies: A view from the Western borderlands. London; New York: Routledge. https://doi.org/10.4324/9781315226583. 
Annus, Epp, ed. 2018b. Coloniality, Nationality, Modernity: A Postcolonial View on Baltic Cultures under Soviet Rule. London; New York: Routledge.

Arendt, Hannah. 1951. The Origins of Totalitarianism. New York: Harcourt, Brace \& Co.

Duara, Prasenjit. 2018. “Comment." In Debating New Approaches to History, edited by Marek Tamm and Peter Burke, 64-69. London: Bloomsbury.

Eagleton, Terry. 1999. “In the Gaudy Supermarket." London Review of Books 21 (10): 3-6. https:// www.Lrb.co.uk/v21/n10/terry-eagleton/in-the-gaudy-supermarket.

Fitzpatrick, Sheila. 1999. Everyday Stalinism: Ordinary life in extraordinary times: Soviet Russia in the 1930s. New York: Oxford University Press.

Getty, J. Arch. 1985. Origins of the Great Purges: The Soviet Communist Party reconsidered, 19331938. Cambridge; New York: Cambridge University Press.

Hosking, Geoffrey. 2001. Russia and the Russians: A history. Cambridge, MA: Belknap Press.

Kotkin, Stephen. 1995. Magnetic Mountain: Stalinism as a civilization. Berkeley [etc.]: University of California Press.

Majumdar, Rochona. 2018. “Postcolonial History." In Debating New Approaches to History, edited by Marek Tamm and Peter Burke, 49-64. London: Bloomsbury.

Sebag Montefiore, Simon. 2008. Noor Stalin. Tallinn: Varrak.

Kaarel Piirimäe-associate professor at the Institute of History and Archaeology of the University of Tartu and senior research fellow at the Estonian War MuseumGeneral Laidoner Museum.

e-mail: kaarel.piirimae[at]ut.ee

\section{Postcolonial cosmology or postcolonial critique? A response to Kaarel Piirimäe}

Epp Annus

DOI: $10.7592 /$ methis.v17i21/22.14671

It was with considerable pleasure that I read Kaarel Piirimäe's words of praise for my Soviet Postcolonial Studies: A View from the Western Borderlands. I know-as Piirimäe himself confesses in his review - that he is not a very sympathetic reader of this kind of work, generally speaking, so I was all the more gratified that he found himself broadly in sympathy with my reading of the Soviet Union as a colonial power and that, whatever his minor reservations, he found the generosity to call the book "required reading for anyone interested in the Soviet legacy in the Baltic countries." 
I am convinced that most of Piirimäe's minor reservations are, in fact, minor misreadings of local points in my book. For present purposes, however, I think I will desist from explaining in detail how my point was not that the Soviet project entailed an "equal treatment of men and women", but rather that the Soviet state made "efforts to advance" such equal treatment; or how my point was not a general claim that "cultural abundance was available only for manual workers", but about a specific kind of cultural abundance typified by kolkhoz trips to theatres. I do indeed write that "girls and boys cease to exist, pioneers and students take their places"but the context of its appearance belongs to a description of Madis Kõiv's childhood recollection, in which Kõiv describes the alienating effects produced by the new Soviet school books, translated from Russian and full of happy young pioneers (in lieu of the happy girls and boys of pre-Soviet school books). So I was describing not Soviet-era realities, but rather a child's feeling of alienation-filtered, of course, through specific practices of storytelling and remembering. I regret that I did not make this clear enough for readers like Piirimäe.

And yet there are several more substantive points we might profitably take up from Piirimäe's review and consider at greater length, in the spirit of scholarly dialogue. And, again, I am grateful to Kaarel Piirimäe for his review and to the editors at Methis for this opportunity.

\section{Does post-colonial studies adhere to a cosmology?}

The first of these more substantive points regards the general question of postcolonial approaches and their potential role within Soviet studies. In his review, Kaarel Piirimäe makes some very strong claims. For example, he offers the view of an "ordinary historian" that postcolonialism "is not scholarship but an effort, a successful one, to bring the anti-colonial struggle into the heart of the former metropolises, and therefore primarily a political, not a scholarly, endeavour". I think Piirimäe is too dismissive here of other scholarly modes.

To start with some basic points, it is useful to remind ourselves that whenever we talk about "postcolonial critical theory" or "postcolonial theory", we are dealing with a huge body of work which includes myriad different approaches-some of them indeed politically attuned, some others written for scholarly audiences, some of them based on archival research, some on oral histories, some on readings of literature, film or media texts. Very often readers might see an author focused upon presenting or explicating a specific phenomenon, but without striving for any broader generalization. And yet it must be said that narrow research without the generalizing impulse is less likely to reach general audiences. Thus those interested in postcolonial approaches are more likely to click on an article like "Of mi- 
micry and man: The ambivalence of colonial discourse" lone of Homi Bhabha's most widely read texts), rather than on "From Cybermohalla to Trickster City: Writing from the margins of Delhi" la recent article by Lipi Biswas Sen in Journal of Postcolonial Writingl-unless, that is, the reader is specifically interested in Delhi or in the Cybermohalla project (the abstract of this article, by the way, looks really interesting!). For these reasons, it is easy for casual observers, attracted to the most generalizing articles of the field, to get a misleading sense of the general tendencies of what is, after all, an enormous field of postcolonial inquiry.

For the reasons of the vastness of the field, I generally refer in my book to "postcolonial studies" (thus "Soviet postcolonial studies"), not to postcolonial "theory". I myself use the phrase "postcolonial theory" only a few times in the book and then referring specifically to certain attitudes that, as I argue, would profit from critical revision. For example, my book argues that "Postcolonial critique developed as a critique of domination that was specifically capitalist; one of its preconditions has been an understanding of imperialism as connected to the emergence of capitalism" (Annus 2018, 87). Following from this, I suggest that the link between imperialism and capitalism needs to be revisited, since imperial and colonial attitudes are not limited to capitalist economies alone, and I point out that such a theoretical correlation has hindered the development of postcolonial approaches in analyses of Soviet societies.

Piirimäe's dissatisfaction with certain aspects of my book is something that he attributes largely to postcolonial theory itself. For Piirimäe, “This is in many respects an admirable book [...] It suffers only from the ambition of postcolonialism to offer a kind of total interpretive paradigm and the author's wish to engage with that cosmology at all cost." I must confess that this is not how I understand my own relation to postcolonial paradigms and I would offer, as an example of my own critical relation to postcolonial studies, my revisionist attitude towards fundamental postcolonial categories-including, for example, an effort to completely rethink the use of concepts like the "colonizer" and the "colonized". Leaving aside my own relation to this field of thought, however, I argue in the book that postcolonial paradigms don't have the closure of dogma (or they shouldn't) and they require a responsible revision by each scholar according to the exigencies of the material at hand and the disposition of the scholar him- or herself:

[. . .] a scholar sympathetic to postcolonial paradigms still has to formulate his or her own scholarly approach to fit a specific scholarly inquiry. This book, in the wake of recent developments in critical thought, suggests a critical model, under the umbrella of postcolonial studies that would combine a number of different philosophical approaches. (Annus 2018, 19) 
So for me-and surely not only for me-postcolonial approaches do not prescribe a methodology and I am surprised to read of it described as a distinct cosmology. My book puts it this way: "Postcolonial studies, as it has developed through recent decades, has thought extensively about cultural ruptures and unhomely encounters, about the ensuing strategies of accommodation and hybridisation of identities, and about the ways colonial power-structures condition subject positions" (Annus 2018, 1-2). The framework of postcolonial studies provides a certain critical impulse, it orients scholars towards certain questions-such as ethnic tensions and cultural hybridisations, for example. Postcolonial studies also provides a basic, working vocabulary that can be extended or overwritten according to one's specific research aims. I call my own approach "an effort in multidimensional critical thinking" (36), one heavily indebted not only to postcolonial studies, but also to wider developments in cultural and political philosophy-and, in consequence, hopefully resisting reduction to one single "total interpretive paradigm".

2. Nonconsensual control or manufacture of consent?

Let us consider another important topic that Piirimäe introduces: the manufacture of consent for the Soviet regime. I write that the Soviet Union "did not necessarily govern its borderlands through non-consensual control, but it instead manufactured consent through complex strategies of rule, including various kinds of systemic violence" (47). Kaarel Piirimäe counters this argument with the story of his grandfather, who, like many others after the 1949 mass deportations, was given a choice between Siberia and the kolkhoz; his grandfather, together with others, chose the latter. It was not much of a choice, as I think we can all agree. Such bluntforce cases suggest to Piirimäe the unsuitability of "fancy language"-the unsuitability, that is, of concepts such as the manufacture of consent. I think Piirimäe is too hasty here in discarding a useful concept merely because it seems not to fit such instances as his grandfather's (forced) choice.

Let me briefly summarize my argument: I suggest that "the Soviet regime could not have survived through the decades by nonconsensual control alone" (36). The next question thus follows logically: how then was the consent produced? I see the manufacture of consent as a process which remained uncompleted in the Baltic corner of the USSR (150). According to the model proposed in the book, the initial consent in the Baltics was produced by coercive means; I claim that we should "understand consent not in opposition to violence, but rather within the framework of systemic violence" (39). I see manufactured consent as conditional, or as I put it, “'consent but not quite', consent with a difference-consent until dissent becomes a possibility" (39). Thus the important part here is the process: this process was 
initiated in the formerly independent Baltic States through coercion. Acceptance of the kolkhoz system was indeed forcibly imposed upon people, including Piirimäe's grandfather, but it was also the first of many steps in a process that came to produce, to "manufacture", something like consent, as it was then followed by voting in meetings, then children joining Communist youth organizations, and parents sitting in school concerts where children sang odes to Stalin. This is "consent but not quite". People were subjected to an ongoing process of manufacturing consent, and many produced supportive noises to the regime when it was expected of them.

Piirimäe also points out-and quite correctly-that a certain variance emerges in my book on these matters. From one perspective, the book deploys notions like "manufacture of consent", while at the same time there are examples of nonconsensual control in great abundance-Soviet-era mass deportations are a common example of nonconsensual control appearing in the book. Yet the book is dealing with different political aims and impulses, different polices and different modes of implementation developing over the many years of Soviet rule.

Piirimäe refers to early developments in Soviet studies, in which the "totalitarian" research paradigm came to be heavily contested by revisionists. It is indeed useful to keep in mind that Soviet studies have evolved significantly past its earlier totalitarian model-in fact so significantly past it that some of the claims of the revisionists, who refuted the totalitarian model, have themselves also been refuted in turn (Hoffmann 2003, 2-6). Extreme coercion is still-or is once again-regarded as the major characteristic of Stalinist rule; David Hoffmann defines Stalinism through "policies characterized by extreme coercion employed for the purpose of economic and social transformation" (Hoffmann, forthcoming). Soviet rule included many controversies and internal inconsistencies; it evolved and changed substantially over its decades; it included a chronic mismatch between its policies and its shared practices. I do indeed make the strong claim in my book that Soviet rule had to manufacture consent and could have not survived its many decades on nonconsensual control alone. But this is far from contesting the sometimes systematic and sometimes random deployment of nonconsensual control and extreme state violence that characterised Stalinist rule.

It might also be useful to remind ourselves, as my book constantly tries to do, that Soviet rule in Russia and Soviet rule in the Baltics were distinct in many ways, and so likewise was the popular response to it. Thus scholarly claims about the regime based on Russian materials can be quite ill suited for describing the Baltic experience-and, correspondingly, work with Baltic materials does not necessarily suit Soviet studies interpretive paradigms that developed primarily from Russian material. To give one example from archival materials: a 1937 letter, addressed to 
the Central Committee of the Communist Party, includes urgent complaints against the groundless arrests made by provincial bodies of the NKVD. Kh. Ivanova writes: “The women are writing to our dear Stalin, to Yezhov and Vyshinsky, but apparently none of these letters are getting there. They are obviously being destroyed in the localities" (Siegelbaum and Sokolov 2000, 233). While in Russia it was possible to imagine that "dear Stalin" knew nothing of the atrocities committed in the provincial towns, such position would have been quite unlikely in the Stalin-era ethnic Baltic communities in Estonia, Latvia and Lithuania. Such discrepancies are among the main reasons why a postcolonial angle seemed especially well suited for the study of the Soviet-era Baltics: the specifics of the Soviet-era Baltic situation, with its ethnic and cultural differences, brought along its own sets of tensions.

\section{Back to "sweeping generalizations"?}

The third substantive point I would like to take up from Piirimäe's review regards the specific resistances to coloniality posed by modern nation states and the specific tactics therefore required by any would-be colonizer of a modern nation state. I argue:

To establish a colonial-type political, economic, and cultural order in a developed modern nation-state requires deportations and executions on a massive scale, the devastation of existing social and political structures, and the eradication of the former governing classes, including a significant part of the cultural, military, and economic elite. (Annus 2018, 101)

My point here being that a colonial-type order cannot be imposed upon a modern nation-state without remarkable destruction and violence. Piirimäe calls this “a sweeping generalization" and a result of the "author's wish to engage with [postcolonial] cosmology at all cost". This is indeed a generalization, but one justified by the context of the massive violence that accompanied the establishment of Soviet rule- not only in the Baltics, but also elsewhere in the Soviet Union and all over the Eastern bloc, as my book laid out in its earlier pages. I continue with the claim that such a regime needs for its sustenance a huge control apparatus. This became possible in the advanced phase of modernization, where massive resettlement operations and the establishment of elaborate surveillance systems involved a complicated apparatus of bureaucracy and well-developed logistics of suppression (101).

Piirimäe extracts from this a claim that massive resettlement operations necessitated an advanced phase of modernization and he reminds his reader of premodern mass resettlements in ancient Mesopotamia. Yet my claim was not 
about making an absolute connection between modernization and mass resettlements, but rather that the modern control apparatus, with its well-developed systems of bureaucracy, logistics, and surveillance, became an integral part of how Soviet-era resettlements were organized. It had, with modern technologies of rule, become possible to compose lists, collect and transport tens of thousands of people thousands of kilometres away-and to do so in quite speedy ways; this modern efficiency was a necessary part of the effort to establish a regime of coloniality in the Baltics.

In short, Piirimäe's review-and my book, as I would like to think-gives us an occasion to consider some important questions regarding the disciplinary inclinations of postcolonial studies, questions regarding the complex relation of manufacture of consent to systemic violence, and questions regarding the precise part played (or not played) by modernity, as such, in character of the mass resettlements of the Soviet era. Students and scholars of this material will, I hope, find the time to read my book and Piirimäe's gracious review and come to their own conclusions.

\section{Re fere n c e s}

Annus, Epp. 2018. Soviet Postcolonial Studies: A view from the Western borderlands. London; New York: Routledge. https://doi.org/10.4324/9781315226583.

Hoffmann, David L. 2003. "Introduction: Interpretations of Stalinism." In Stalinism: The Essential Readings, edited by David L. Hoffmann, 1-7. Oxford: Blackwell.

---. Forthcoming. The Stalinist Era. Cambridge: Cambridge University Press.

Siegelbaum, Lewis, and Andrei Sokolov. 2000. Stalinism as a Way of Life. A Narrative in Documents. New Haven and London: Yale University Press.

Epp Annus-Ph.D in Estonian Literature (2002, University of Tartu), senior researcher at the Estonian Literary Museum.

e-mail: epp.annus[at]gmail.com 